\title{
Hadislerde "Dünya" ve "Arz" Kelimeleri -Buhârî Örneği-
}

BEKIR TATLI

DR., ÇUKUROVA Ü. İLÂHIYAT FAKÜLTESI

e-posta: btatli@cu.edu.tr / tatlibekir@yahoo.com

\begin{abstract}
Using Words of "Dunya" and "Ard" in the Narrations - Example of Bukhari. We generally use words of "dunya" (الدنيا) and "ard" (الأرض) (earth, world) in Turkish for a planet like the Sun and the Moon in the space. But the Qoran separates each one and uses them for different meanings. We have wondered also using of them in the narrations but there are a lot of narrations about this subject. Therefore we have studied only example of Bukhari. In this work we have studied dunya and ard in the narrations of Bukhari's well known book. In the Sahih alBukhari this two words are used in different meanings like Qoran and generally using of them in the Qoran and al-Bukhari is the same.
\end{abstract}

key words

Dunya, Ard (earth, world), Narrations, al-Bukhari

\section{Giriş}

Daha önceki bir çalışmamızda Kur'ân'da "dünya" ve "arz" kelimelerinin nasıl kullanıldığını ele almış ve Türkçedeki yaygın kullanımın aksine âyetlerde bu iki kelimenin kesinlikle birbirlerinin yerine kullanılmadığı sonucuna varmıştık. ${ }^{1}$ Türkçede dünya denildiğinde çoğu zaman bununla üzerinde yaşadığımız yerkürenin kastedildiğini biliyoruz. Kur'ân ise dünyayı "yerküre" anlamında değil "âhiretin" mukabili olarak "ölümden ön-

1 Bkz. Tatlı, Bekir, "Kur'ân'da 'Dünya' ve 'Arz' Kelimelerinin Kullanımı", Ankara Üniversitesi İlâhiyat Fakültesi Dergisi, cilt:46, sayı:2, yıl:2005, ss.259-265. 
ceki hayat safhası" anlamında kullanır ve bu anlamda herhangi bir mekân izafesi söz konusu değildir. Kur'ân'ın yerküre anlamında kullandığ 1 kelime semanın mukabili olan "arz" (الأرض) kelimesidir. Dolayısıyla âyetlerde dünya ve arz kelimeleri eşanlamlı olarak kullanılmamıştır.

Aynı incelemeyi hadisler için de yapmanın faydalı olduğunu düşünüyoruz. Böylece genellikle mana ile rivâyet edildiği düşünülen hadis metinlerinde bu kelimelerin ne derecede dikkatli nakledilmiş olduğu konusunda fikir sahibi olmamız mümkün olacaktır. Bu manada şüphesiz hadis ilminin otoritelerinden biri olan ve kelimeleri büyük bir itinayla seçen ve kullanan biri olarak Buhârî'yi örnek olarak incelemenin daha anlamlı olacağı kanaatindeyiz. Bu gayeyle Buhârî'nin Sahîh'ini göz önünde bulundurarak içerisinde "dünya" ve "arz" kelimelerinin geçtiği çeşitli rivâyetleri inceleyecek ve bunların birbirlerinin yerine müteradif olarak kullanılıp kullanılmadığ konusunda fikir edinmeye çalışacağız. Burada elbette bu kelimelerin geçtiği bütün hadislerin ele alınması mümkün olmadığı için bir kanaat ortaya koyacak kadar örneğin verilmesi yeterli görülecektir. Ayrıca üzerinde durulan rivâyetlerde dünya ve arz kelimelerinin hangi üslupta kullanıldığını daha net görebilmemiz için metinlerin ilgili kısımlarının Arapça olarak verilmesine de gayret gösterilecektir.

\section{Buhârînin Rivâyet Üslûbu}

Asıl konuya girmeden önce Buhârî'nin kitabını nasıl oluşturduğu ve rivâyetleri alırken nasıl bir yol takip ettiği konusunda genel bir bilgi vermenin faydalı olacağını düşünüyoruz. Bilindiği üzere Buhârî es-Sahîh adlı eserini, kendi şartına göre sahih kabul ettiği pek çok sahih rivâyet arasından derlediği hadislerden oluşturmuştur. ${ }^{2}$ Bu eserde yer alan rivâyetler kitap adı verilen bölümlerde genel bir konu başlığı altında bir araya getirilmiş olsa da, bir konuyla ilgili tüm rivâyetler bir arada yer almaz ve değişik kitaplarda yeri geldikçe tekrar edilir. Bu açıdan baktı̆̆ımızda onun Müslim'in kitabına göre daha dağınık olduğu akla gelirse de gerçekte Buhârî'nin

2 Buhârî'nin kendi eserine verdiği isim şu şekildedir: el-Câmiu'l-müsnedu's-sahîhu'l-muhtasaru min umûri Rasûlillah (s.a.) ve sünenihî ve eyyâmihî. (Bkz. İbnu's-Salâh, Ebû Amr Osman b. Abdirrahman eş-Şehrezûrî, Ulûmu'l-hadîs, s. 26, thk. Nureddîn Itr, Beyrut 1406/1986; A'zamî, M., İlk Devir Hadis Edebiyatı, s. 276, trc. Hulûsi Yavuz, İstanbul 1993; Sezgin, M. Fuad, Buhârînnin Kaynakları, s. 208, Ankara 2000.) Kitabına böyle bir ismi vermekle müellif, onda yer alan rivâyetlerin sahih ve müsned olduğunu ilan etmek istemiş olmalıdır. İbnu's-Salâh'ın (ö. 643) kaydettiğine göre Buhârî, kitabına sahih dışında hiçbir rivâyeti dâhil etmediğini, sahih olduğu halde uzun olanları da terk ettiğini beyan etmiştir. Bkz. Ulûmu'l-hadîs, s. 19. Bununla birlikte kitabın isminde yer alan muhtasar kelimesi, eserin bütün sahih hadisleri toplamak gibi bir gayesi olmadığını da açıkça göstermektedir. 
usûlü de rivâyetlerin farklı yerlerde farklı açılarının ortaya konulması ve tekrar imkânı bahşetmesi gibi çeşitli açılardan üstünlük taşır ve muhtelif faydaları bünyesinde barındırır. Buhârî'nin rivâyetleri ahz ve tahammül yani kabul şartlarının diğer müelliflere göre çok daha ağır olduğu bilinir. Sözgelimi, bir râvînin şeyhinden hadis alıp almadığını tespit etmek üzere Buhârî o ikisinin aynı asırda yaşamış olmalarını sıhhat için yeterli görmez ve mutlaka mülâki olmuş yani karşılaşmış ve ondan rivâyet aldığının tespit edilmiş olmasını şart koşar. ${ }^{3}$ Dolayısıyla Buhârî'nin kitabına giren rivâyetlerin diğer hadis musannefâtına nazaran lâfız ve mana açısından çok daha güvenilir olduğunu kabul etmemiz gerekir. Onda bulunan her kelime, müellifi tarafından çeşitli açılardan test edilmiş ve titizlikle seçilmiştir. Bu nedenle Buhârî'nin kitabında dünya ve arz kelimeleriyle ilgili olarak ele alacağımız bu çalışmanın, hadis kitaplarında nakledilen rivâyetlerin ne derece dikkatli nakledilip edilmediği konusunda bizlere azami ölçüde fikir verebileceğine inanıyoruz.

\section{Sahîhu'l-Buhârî'de "Dünya" (الدنيا) Kelimesinin Kullanımı}

Buhârî'nin bu eserinde yer alan rivâyetlerde dünya kelimesinin çeşitli anlamlarda kullanıldığı dikkat çekmektedir. Bunları şu şekilde özetlememiz mümkündür:

\section{Dünya kelimesinin sözlük anlamı itibariyle kullanımı.}

Bu durumda dünya Arapça "dünüvv" (yakınlık) kökünden gelir, "en yakın" anlamında ve genellikle semanın bir sıfatı olarak kullanılır.

Dünyanın bu anlamda kullanıldı̆̆ı rivâyetlerden birisi Mi'râc hâdisesinin anlatıldı̆̆ 1 rivâyetlerdir. Bu rivâyetlerde Hz. Peygamber'e gece yolculuğunda rehberlik eden Cibrîl'in Rasûlullah ile "en yakın semaya" السماء) الدنيا yükseldiği anlatılır. ${ }^{4}$

3 Mesela bkz. Itr, Nureddîn, Menhecu'n-nakd fî ulûmi'l-hadîs, s. 256, Beyrut 1412/1992; Koçyiğit, Talat, Hadîs Tarihi, s. 260, Ankara 1988; Çakan, İsmail Lütfi, Hadîs Edebiyatı, s. 66, İstanbul 1989; Sandıkçı, Kemal, Sahîh-i Buhârî Üzerine Yapılan Çalışmalar, s. 17, Ankara 1991.

4 Ebû Zerr'den gelen rivâyetler: Buhârî, Ebû Abdillah Muhammed b. İsmâil el-Cu'fî, Sahîhu'lBuhârî, I-VII, Beyrut, 1410/1990, Salât 1 (no: 342, dört defa dünya kelimesi kullanılmıştır ve hepsi de sözlük anlamıyladır.), Hac 75 (no: 1555), Enbiyâ 7 (no: 3164). Enes b. Mâlik'ten gelen rivâyet: Tevhîd 37 (no: 7079). Enes b. Mâlik- Mâlik b. Sa'saa kanalıyla gelenler: Bed'ü'lhalk 6 (no: 3035), Fezâilu's-sahâbe 71 (no: 3674). 
Dünyanın sözlük anlamıyla kullanımına diğer bir örnek, Rabbimizin her gece belli vakitte en yakın semaya (السماء الدنيا) tenezzül ettiğgini/indiğini anlatan rivâyettir. ${ }^{5}$

Yine yolları/caddeleri karış karış gezen melekler topluluğunun, Allah'ı zikir ile meşgul insanları görüp onların yanına gelerek en yakın semaya kadar (إلى السماء الدنيا) onları kanatlarıyla örtmeleriyle ilgili rivâyet de diğer bir örnektir. ${ }^{6}$

Konuyla ilgili diğer bir rivâyette ise İbn Ömer'in hacda şeytan taşlama esnasında en yakın cemreye (الجمرة الدنيا) yedi taş attığı belirtilmiştir.7 Yine burada da dünya kelimesi "yakın" anlamında kullanılmış olmaktadır.

Buradaki rivâyetlerde söz konusu edilen dünya, semanın yeryüzüne en yakın kısmı olup, kanaatimizce bunun "dünya seması" şeklinde çevrilmesi doğru değildir. ${ }^{8}$

\section{Dünya kelimesinin âhiretin mukabili olarak kullanıldığı yerler.}

Rivâyetlerin çoğunda dünya kelimesi âhiretten/ölümden önceki hayat safhasını anlatmak için kullanılır. Bazı rivâyetlerde bu daha açıtır ve dünya kelimesi âhiret veya aynı anlamdaki diğer bir kelimeyle birlikte kullanılır. Dolayısıyla dünya kelimesinin bu anlamdaki kullanımında da yine herhangi bir mekân anlamı söz konusu değildir.

Dünyanın âhiretin mukabili olarak kullanıldığı bazı rivâyetler şöyledir:

"Peygamber (s.a.) bir gece uyandı ve şöyle buyurdu: Sübhânallah! Bu gece ne fitneler indirildi ve ne hazineler açıldı! Odalardaki arkadaşlarınızı uyandırın! Dünyada nice giyimli kadın vardır ki âhirette çıplaktır!"9 رب) (كاسية في الانيا عارية في الآخرة

5 Ebû Hureyre rivâyeti için bkz. Buhârî, Teheccüd 14 (no: 1094), Deavât 13 (no: 5962), Tevhîd 35 (no: 7056).

6 Ebû Hureyre rivâyeti için bkz. Buhârî, Deavât 66 (no: 6045).

7 Buhârî, Hac 139 (no: 1664), 140 (no: 1665).

8 Erzurumlu İbrahim Hakkı Hazretleri'nin Mârifetnâme adlı eserinde âlemin yaratılışı ile ilgili bölümde "Dünya Semâsı ve İçindekiler" adında bir başlık vardır. Bu bölümde müellif, Hak Teâlâ'nın dünya gögü altında ve ona bitişik bir su denizi yarattığını, bu denizin dünya göğünün içini kapladığını anlatır. Ayrıca yedi kat gökten bahsederken de, yedi göŏün topluluklarının ve şekillerinin sahih rivâyetler üzere çadırlar misali olduğunu, yerin çevresinde bulunan sekiz Kaf Dağı'nın yedisi üzerinde karar ettiklerini; sekizinci Kaf Dağı'nın da dünya göğünün içinde yeri kuşattığını ifade eder. Bkz. Mârifetnâme, s. 39, sadeleştiren: M. Fuad Başar, İstanbul, ts.

9 Ümmü Seleme'den gelen rivâyetler için bkz. Buhârî, İlim 40 (no:115), Teheccüd 5 (no: 1074), Libâs 30 (no: 5506), Edeb 121 (no: 5864), Fiten 6 (no: 6658). 
"Rabbimiz! Bizlere dünyada da âhirette de iyilik في الانيا حسنة وفي الآخرة) ( ver ve bizi ateşin azabindan koru!"10

"Ben bütün müminlerin dünya ve âhirette en yakın velîsiyim."11

$$
\text { (ما من مؤمن الا و أنا أولى به في الدنيا والآخرة) }
$$

"Gerçekten Allah bir kulu dünya ile kendi katındaki şey arasında muhayyer buraktı (خبر عبدا بين الدنبا وبين ما عنده) da o kul Allah katında olanı tercih etti..."12 Hz. Âişe de aynı anlamda şu ifadeleri kullanır: "Ben, hiçbir peygamberin dünya ile âhiret arasında tercih yaptırlmadan حنى يخير بين الدنيا) ) والآخرة

"Dünyada içki içip de (شرب الخمر في الدنيا) tevbe etmeyen, âhirette ondan mahrum kalır."14

"Dünyada ipek elbise giyen (يلبس الحرير في الدنيا) âhirette giyemez."15

"Rasûlullah (s.a.), doyasıya arpa ekmeği yemeden bu dünyadan ayrldi."16 (خرج رسول اله ص. من الدنيا)

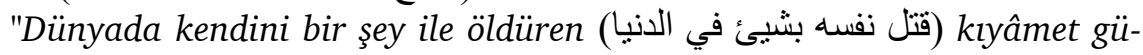
nünde onunla azap görür."17

"Allah'a hiçbir şeyi ortak koşmamanız, hırsılılı yapmamanız, zina etmemeniz, çocuklarınızı öldürmemeniz, birbirlerinize iftira atmamanız ve iyilik konusunda isyan etmemeniz hakkında bana bey'at edin. Bunlart tam yerine getirenin mükâfatı Allah'a aittir. Kim bunlardan birini ihlal eder de dünyada cezalandirllursa (فعوقب في الدنبا) o ona keffaret olur. Bunlardan birini yaptı̆̆ halde Allah onu örterse, durumu Allah'a kalmıştır; isterse onu affeder, isterse cezalandirtr..."18

"Bana cennet gösterildi de ondan bir üzüm salkımı almaya niyetlendim. Şayet onu alsaydım, dünya devam ettiği sürece (ما بقيت الدنيا) elbette ondan yerdiniz."19

10 Enes rivâyeti için bkz. Buhârî, Tefsîr 38 (no: 4250), Deavât 55 (no: 6026).

11 Ebû Hureyre rivâyeti için bkz. Buhârî, İstikrâz 11 (no: 2269), Tefsîr 273 (no: 4503).

12 Ebû Saîd el-Hudrî'den nakledilen rivâyetler için bkz. Buhârî, Mesâcid 46 (no: 454), Fezâilu'ssahâbe 3 (no: 3454), 74 (no: 3691).

13 Buhârî, Meğâzî 78 (no: 4171). Krş. Tefsîr 92 (no: 4310).

14 İbn Ömer rivâyeti için bkz. Buhârî, Eşribe 1 (no: 5253).

15 Ömer rivâyeti: Buhârî, Libâs 24 (no: 5492, 5497); Enes rivâyeti: Libâs 24 (no: 5494); İbnu'zZübeyr rivâyeti: Libâs 24 (no: 5495, 5496).

16 Ebû Hureyre rivâyeti için bkz. Buhârî, Et'ıme 24 (no: 5098).

17 Sâbit b. ed-Dahhâk rivâyeti için bkz. Buhârî, Edeb 44 (no: 5700).

18 Ubâde b. es-Sâmit'ten gelen rivâyetler için bkz. Buhârî, İman 9 (no:18), Fezâilu's-sahâbe 72 (no: 3679), Hudûd 14 (no: 6416), Ahkâm 49 (no: 6787), Tevhîd 31 (no: 7030).

19 Abdullah b. Abbas'tan gelen rivâyetler için bkz. Buhârî, Sifatu's-salât 9 (no: 715), Küsûf 9 (no: 1004), Nikâh 87 (no: 4901). 
"Dünyada (في الدنيا) sanki bir yabanct yahut yolcu gibi ol."20

Hz. Ömer Rasûlullah'ın bir peygamber olmasına rağmen çok sıkıntılar çekmesine mukabil, saraylarda rahat içerisinde hayat süren kişilerden yakındığı zaman Hz. Peygamber onu şöyle teselli etmiştir: "Ey Ömer! İstemez misin dünya onlarm, âhiret bizim (لهم الدنيا ولنا الآخرة) olsun?"21 Yine Peygamber Rum ve İran idarecilerinin içinde bulundukları şatafatlı durumu, "dünyanın onlara verilmesi" (و أعطو ا الدنيا) ve "iyiliklerinin karşılığının dünya hayatında peşin ödenmesi" (عجلو ا طيباتهم في الحياة الدنيا) olarak nitelemiştir. ${ }^{22}$

Ammâr tarafından Peygamber Efendimizin "dünya ve âhirette zevcesi" olduğu (زوجته في الدنياو الآخرة) ifade edilen ${ }^{23} \mathrm{~Hz}$. Âişe, Rasûlullah'ın, zaman zaman ilk eşi Hz. Hatice hakkında kullandı̆̆ı övgü dolu sözler sebebiyle duyduğu rahatsızlığını ortaya koymuş ve çoğu zaman ona: كأنه لم يكن في) ( "Sanki dünyada Hatice'den başka kadın yok!" diyerek kıskançlığını açıç̧a ifade etmekten çekinmemiştir. ${ }^{24}$ Bununla birlikte Âişe, Rasûlullah'a duyduğu büyük aşkı onun vefat anından bahsederken şu sözlerle ifade etmiştir: "Allah, onun bu dünyadaki son, âhiretteki ilk gününde

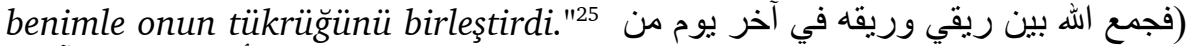
( الدنيا وأول يوم من الآخرة

Hz. Peygamber'in namazı tarif edilirken şu ifadeler kullanılır: "İşte bu, onun dünyadan ayrılıncaya kadar (حتى فارق الدنيا) klldığı namazdır."26

Rasûlullah özel duaları esnasında genellikle "dünyanın fitnesinden" من فلانيات فتنة الدنيا Allah'a sığınırdı. ${ }^{27}$

Ümmü'd-Derdâ, kocasının zühd hayatında çok ileri gittiği, kendini tamamen âhirete yönelik ibâdetlere verdiği ve kendisini ihmal ettiği konusunda Selmân-1 Fârisî'ye sitemde bulunurken: أخوك أبو الدرداء ليس له حاجة) (Kardeşin Ebû'd-Derdâ'nın dünyaya ihtiyacı kalmadı!"28 ifadelerini kullanmıştır.

20 İbn Ömer rivâyeti için bkz. Buhârî, Rikâk 3 (no: 6053).

${ }^{21}$ İbn Abbas rivâyeti için bkz. Buhârî, Tefsîr 387 (no: 4629).

22 İbn Abbas rivâyeti için bkz. Buhârî, Nikâh 83 (no: 4895), Mezâlim 26 (no: 2336).

23 Buhârî, Fezâilu's-sahâbe 30 (no: 3561), Fiten 17 (no: 6687, 6688).

${ }^{24}$ Buhârî, Fezâilu's-sahâbe 50 (no: 3607).

25 Buhârî, Meğâzî 78 (no: 4186).

${ }^{26}$ Ebû Hureyre'den nakledilen rivâyet için bkz. Buhârî, Sıfatu's-salât 44 (no: 770).

27 Sa'd b. Ebî Vakkas'tan nakledilen rivâyet için bkz. Buhârî, Cihâd 25 (no: 2667), Deavât 36 (no: 6004), 40 (no: 6009), 43 (no: 6013), 56 (no: 6027).

28 Buhârî, Savm 50 (no: 1867), Edeb 86 (5788). 
Verilen misallerde açıkça görüldüğü üzere rivâyetlerde dünyanın âhiretin mukabili olarak ölümden önceki hayat anlamında kullanılması son derece yaygindır.

1. Dünya kelimesinin üzerinde yaşadığımız "yeryüzü" anlamında kullanılması. Bu durumda onunla "çok geniş bir alan" kastedilir. Bunun örneği olabilecek bir rivâyette, cehennemden en son çıkıp cennete en son girecek kişiye cennette verilecek nimetler şu ifadelerle anlatıliyor:

"Git ve cennete gir. Dünya ve onun on misli (مثل الدنيا وعشرة أمثالها) senindir." 29

"Şüphesiz benden sonra sizin için korktuğum şey, dünyanın güzelliğinin ve süslerinin (زهرة الدنيا وزينتها) sizlere açılmış olmasıdır." ${ }^{130}$ Bu rivâyetteki "dünyanın güzelliği" ifadesi diğer bir rivâyette "yeryüzünün bereketleri" (بركات الأرض) şeklinde kaydedilmiştir. ${ }^{31}$

Bu örneklerde açık bir şekilde üzerinde yaşadığımız yeryüzünün genişliğine vurgu yapılmaktadır. Dolayısıyla "dünya" kelimesi ile bir mekân kastedilmiş olmakta ve bu anlamda "arz" ile müteradif bir kullanım ortaya çımmaktadır. Bu durumda dünya âhiretin mukabili olarak değil, yeryüzünü anlatmak için kullanılmış olmaktadır. Ancak rivâyetlerde bu kullanımın yaygın olduğunu söylememiz zordur.

1. Dünya kelimesinin "dünyalık bir menfaat" veya "yeryüzünde bulunan nimetler" anlamında kullanılması da söz konusudur. Sözgelimi, Ebû Zerr'in insanların mal-mülk sevdasına kapılmalarına tepki olarak söylediği şu sözler bunun bir örneğidir:

"Şu insanlar akıllarını kullanmıyorlar ve ancak dünyalık mal-mülk topluyorlar. (يجمعون الدنيا) Hayır, Allah'a yemin ederim ki Allah'a kavuşuncaya kadar ben onlardan dünyalık istemiyorum! (لانيان أسألهم دنيا) Yine onlardan dine dair fetva da isteyecek değilim!"32

Meşhur niyet hadisinde de: "Kimin hicreti de, elde edeceği bir dünyalık/menfaat (الى دنبا يصيبها) yahut nikâhlayacağı bir hanım için olursa, onun hicreti (gerçekte) hicret ettiği şeyedir." ${ }^{133}$ denilerek dünya kelimesi, bir menfaat anlamında kullanılmıştır.

29 Abdullah b. Mes'ûd rivâyeti için bkz. Buhârî, Rikâk 51 (no: 6202), Tevhîd 36 (no: 7073).

30 Aynı anlamda benzer ifadelerle nakledilmiştir. Ebû Saîd el-Hudrî rivâyeti: Buhârî, Zekât 46 (no: 1396); Amr b. Avf el-Ensârî rivâyeti: Cizye 1 (no: 2988), Meğâî̂ 9 (no: 3791), Rikâk 7 (no: 6061); Ukbe b. Âmir rivâyeti: Meğâzî 14 (no: 3816).

31 Buhârî, Cihâd 37 (no: 2687), Rikâk 7 (no: 6063). Bu durumda dünya ve yeryüzü kelimeleri eşanlamlı olarak kullanılmış da olabilir.

32 Buhârî, Zekât 4 (no: 1342).

33 Hz. Ömer'den gelen rivâyetler için bkz. Buhârî, Bed'ü'l-vahy 1 (no: 1), Fezâilu's-sahâbe 74 (no: 3685), Nikâh 5 (no: 4783), Eymân 22 (no: 6311), Hiyel 1 (no: 6553). 
Dünyanın, yeryüzünde bulunan sayısız nimetler anlamında kullanımına ise şu rivâyetleri örnek olarak verebiliriz:

"Allah yolunda sabah veya akşam bir yürüyüş, dünyadan da içindekilerden de daha hayırlıdır."34 (خير من الدنيا وما فيها). Buhârî şârihlerinden İbn Battâl'ın (ö. 449) haber verdiğine göre buradaki "hayrun mine'd-dünya" ifadesini el-Mühelleb "hayrun min zemeni'd-dünya" olarak anlamıştır. ${ }^{35}$ Buna karşılık İbn Dakîykı'l-Iyd (ö. 702), cennette bulunan bir zerrenin bile dünyadaki bütün her şeyden üstün olduğu yönünü dikkatlere sunarak, bu rivâyetteki dünya ile yeryüzünde bulunan bütün nimetlerin kastedilmiş olduğunu hissettirmiştir. ${ }^{36}$

"Allah yolunda bir gün nöbet, dünyadan ve üzerindekilerden daha hayırlıdır. (خير من الدنيا وما عليها) Cennette sizin bir kırbacınızın kapladığı (küçücük) bir yer, dünyadan ve üzerindekilerden daha hayırlıdır. Bir kulun Allah yolunda yaptığı sabah-akşam yürüyüs dünyadan ve içindekilerden daha hayırlıdır."137

Ebû Hureyre'den gelen bir rivâyete göre Rasûlullah (s.a.) Hz. İsa'nın âdil bir hakem olarak insanların arasına ineceği zamanın yaklaştığını, onun haçı kıracağını, domuzu öldüreceğini, cizyeyi koyacağını, malın hiç kimsenin kabul etmeyeceği kadar yaygınlaşacağını söylemiştir. İşte bu

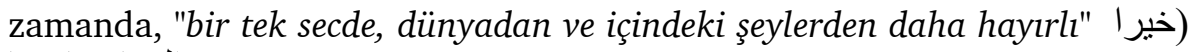
( olacaktır. ${ }^{38}$

Enes b. Mâlik, Tüster kalesinin savunmasında hazır bulunduğu sırada, savaşın kızışması üzerine gün ağarıncaya kadar kılamadığı ve ancak bundan sonra kılabildiği namazı: "Bu namazın bana verdiği süruru dünya ve $i$ çindekiler (الدنيا وما فيها) vermez." diyerek anlatıyor. ${ }^{39}$ İbn Hacer'den (ö. 852) öğrendiğimize göre ez-Zeyn İbnu'l-Münîr, Enes'in namazı dünyaya ve içindekilere tercih etme düşüncesinin altında, fethin elde edilememesi-

34 Enes rivâyeti: Buhârî, Cihâd 5 (no: 2639), 6 (no: 2643), Rikâk 51 (no: 6199); Sehl b. Sa'd rivâyeti: Cihâd 5 (no: 2641), Rikâk 2 (no: 6052). Krș. Cihâd 72 (no: 2735). Burada "dünya ve içindekiler" şeklinde kaydedilen kısım Ebû Hureyre'den gelen bir rivâyette (Buhârî, Cihâd 5, no: 2640) "üzerine güneşin doğduğu ve battı̆̆ her şey" (مما تطلع عليه الثمس وتغرب) olarak yer almıştır. Bu durumda yeryüzü üzerinde bulunan her şey kastedilmiş olur.

35 İbn Battâl, Ebû'l-Hasen Ali b. Halef b. Abdilmelik, Şerhu Sahîhi'l-Buhârî, V, 14, I-X, Riyâd ts.

36 Bkz. İbn Hacer, Ebû'l-Fadl Ahmed b. Ali el-Askalânî, Fethu'l-bârî şerhu Sahîhi'l-Buhârî, VI, 14, I-XIII, Beyrut 1379.

37 Sehl b. Sa'd rivâyeti: Buhârî, Cihâd 72 (no: 2735), Bed'ü'l-halk 8 (no: 3078), Rikâk 2 (no: 6052).

38 Buhârî, Enbiyâ 50 (no: 3264).

39 Buhârî, Salâtu'l-havf 4 (no 903'ün öncesi). 
ne bile mal olsa, bir namazı zamanında eda etmenin daha üstün olduğuna inanmasının yattığını söylemiştir. ${ }^{40}$

Muhammed b. Sîrîn (ö. 110), tâbiûnun büyüklerinden Abîde b. Amr es-Selmânî'ye: "Enes'ten yahut Enes'in ailesinden bize ulaşmış Peygamber'in (s.a.) saçından bir parça var." dediğinde Abîde buna şöyle karşılık verir: "Benim yanımda ondan bir parça saç olması, bana dünyadan ve onun içindekilerden daha sevimlidir."41 (أحب الي من الدنيا وما فيها)

Burada sıralamış olduğumuz örneklerde dünyanın daha çok genişliğine ve nimetlerinin çokluğuna vurgu yapılmıştır.

Genel bir değerlendirme yapmak gerekirse; Buhârî'nin kitabında yer alan rivâyetlerin büyük çoğunluğunda dünya kelimesi "âhiretin mukabili" olarak kullanılmış, onunla yeryüzü kastedilmemiştir. Bununla birlikte bu kelimenin sözlük anlamı itibariyle "yakınlık" veya "yeryüzü" ve onun üzerinde bulunan "geniş nimetler" manasında kullanıldığına dair örnekler de vardır.

\section{Sahîhu'l-Buhârî'de "Arz" (الأرض) Kelimesinin Kullanımı}

Arz kelimesi de rivâyetlerde sıklıkla yer almaktadır. İnceleyebildiğimiz kadarı ile bu rivâyetlerde geçen arz genellikle şu anlamlardan birinde kullanilır:

\section{Arzın toprak, arazi, arsa ve yer gibi anlamlarda kullanılması.}

Bu manadan olarak (أهل الأرض) ehlu'l-arz"22, (ربّ الأرض) rabbu'l-arzz"3 ve (سيد الأرض) seyyidu'l-arz"4 ifadeleri "toprak sahibi" anlamina gelir. Söz konusu kelimenin toprak, yer, arazi ve arsa gibi anlamlarda kullanımına dair şu örnekleri vermemiz mümkündür:

\footnotetext{
40 İbn Hacer, Fethu'l-bârî, II, 436. İbn Hacer'in ilerleyen satırlarda yaptığı değerlendirmelerden, ez-Zeyn'in bu görüşünü doğru bulmadığı anlaşılmaktadır. Bkz. age., aynı yer.

41 Buhârî, Vudû 32 (no: 168). Tâbiûnun büyüklerinden Ebû Amr Abîde b. Amr es-Selmânî elMurâdî el-Kûfî, Hz. Peygamber dönemine yetiştiği halde onunla görüşememiş (muhadram) kişilerdendir. İbn Hacer'in beyanına göre, fakîh ve sebt (sağlam) bir kişi olup, hicrî 70 yılından önce vefat etmiştir. Bkz. Takrîbu't-Tehzîb, s. 654 (no: 4444), Riyad 1416.

42 Buhârî, Hibe 33 (no: 2487).

43 Buhârî, Muzâraa 14 (bab başlı̆̆ında).

44 Buhârî, Muzâraa 6 (no: 2202).
} 


\begin{abstract}
"Kim arazi konusunda bir karlş (قبد شبر من الأرض) hakstzllk ederse, onun yedi katı o kişinin boynuna dolanır!"45

"Allah'ın benimle birlikte gönderdiği hidâyet ve ilim, toprağa inen أصاب) ( ) bol yağmura benzer..."46

Rasûlullah (s.a.) bir cenazede bulunuyordu. Eline bir dal parçası alıp yere bir çizgi çizdi (ينكت في الأرض) ve şöyle buyurdu: "Sizden her birinizin cehennemden veya cennetten oturacağı yeri yazılmıştır..."47
\end{abstract}

Hz. Âişe Rasûlullah'a Beytullah'ta bulunan duvarın Beyt'e ait olup olmadığını, ona aitse niçin yapılırken dâhil edilmediğini, ayrıca kapısının yüksekte olmasının sebebini sormuştu. Hz. Peygamber o duvarın Beyt'e ait olduğunu ama o zaman için maddî imkânsızlıklar sebebiyle hariçte kaldığını; kapısının ise her isteyenin girememesi için yüksek yapıldığını söylemiş ve şöyle eklemiştir: "Şayet senin kavmin câhiliyyeden yeni kurtulmuş olmasaydı ve ben de onların kalplerinin karşı çıkacağından korkmasaydım, duvarı Beyt'e dâhil eder ve (وأن ألصق بابه في الأرض) kapısını da yere yapıştırırdım." ${ }^{148}$

Hz. Peygamber'in anlattığına göre adamın biri diğerinden bir gayr-i menkul/arazi satın alır. Bir müddet sonra orada içinde altın bulunan bir testi bulur. Hemen araziyi satın aldığı kişiye giderek altını onu vermek ister. Çünkü gerçekte ondan araziyi satın aldığını (اشتريت منك الأرض), altını satın almadığını söyler. Ancak arazinin eski sahibi araziyi içindekilerle birlikte sattığııı (انما بعتلك الأرض وما فيها) söyleyerek altını almayı reddeder. Neticede konu yargıya taşınır ve onların çocuklarının evlenmesi, altının ise onların masraflarına harcanması şeklinde aralarında hükmolunur. ${ }^{49}$

Hz. Âişe'nin anlatımından öğreniyoruz ki Peygamber (s.a.), vefatıyla sonuçlanan hastalığında ağırlaştığı ve ağrıları arttı̆̆ı zaman iki kişinin (Abbas ve Ali) yardımıyla dışarı çıkmıştı. Bu sırada onun yerde sürünen iki ayağı toprağın üstünde bir hat/çizgi çiziyordu. ${ }^{50}$ (تخط رجلاه في الأرض)

Enes b. Mâlik diyor ki: "Bizler Hz. Peygamber ile birlikte şiddetli sıcaklıkta namaz kılardık. Öyle ki (sıcaktan dolayı) bizden biri alnını toprağa

45 Âişe rivâyeti: Buhârî, Mezâlim 14 (no: 2321), Bed'ü'l-halk 2 (no: 3023); Saîd b. Zeyd rivâyeti: Mezâlim 14 (no: 2320), Bed'ü'l-halk 2 (no: 3026); İbn Ömer rivâyeti: Mezâlim 14 (no: 2322), Bed'ü'l-halk 2 (no: 3024$)$.

46 Ebû Musa rivâyeti için bkz. Buhârî, İlim 20 (no: 79).

${ }^{47}$ Hz. Ali'den nakledilen rivâyet için bkz. Buhârî, Tefsîr 436 (no: 4663), 439 (no: 4666), Edeb 120 (no: 5863), Kader 3 (no: 6231), Tevhîd 54 (no: 7113).

48 Buhârî, Temennî 9 (no: 6816).

49 Ebû Hureyre rivâyeti için bkz. Buhârî, Enbiyâ 52 (no: 3285).

${ }^{50}$ Hz. Âişe'den gelen rivâyet için bkz. Buhârî, Vudû 44 (no: 195), Cemâat 11 (no: 634), 38 (no: 680), 39 (no: 681), Hibe 13 (no: 2448), Meğâzî 78 (no: 4178), Tib 21 (no: 5384). 
koyamazsa, elbisesini serer ve onun üzerine secde ederdi." ${ }^{\prime 51}$

"Peygamber (s.a.) teyemmüm yaparken avuç içlerini toprağa بكفيه) (الأرض ( vurur, sonra da üflerdi."

İbn Ömer Rasûlullah hayattayken bir arazinin kiraya verilebilmesinin serbest olduğunu (أن الأرض تكرى) söylemiş; ancak daha sonra Hz. Peygamber'in bunu yasaklamış olabileceği ve kendisinin bundan haberinin olmayabileceği ihtimalini düşünerek, arazisini kiraya vermekten كر اء) (الأرض vazgeçmiştir. ${ }^{53}$

Hz. Peygamber için kâtiplik yapan, sonra Hıristiyan olan birinin öldügü zaman gömülmesi olayından bahseden bir rivâyette ise, toprağın onu birkaç defa dışarı fırlattığından (وقد لفظته الأرض) söz edilir.54

Buraya kadar verdiğimiz örneklerde "arz" kelimesinin toprak, arazi, yer ve arsa gibi anlamlarda kullanıldığı sarih olarak ortaya çıkmıştır.

1. Bazen bu kelime arz-ı mukaddese, arz-ı Hicâz ve arz-ı Habeş şeklindeki kullanımlarla belli bir bölgeyi ifade eder. Şöyle ki;

Ebû Hureyre'den nakledilen bir rivâyette geçen bilgilere göre, eceli geldiğinde ilk başta ölmeyi kabullenemeyen Hz. Musa, ölüm meleği ile kendisi arasında geçen karşılıklı konuşmanın akabinde ölmeyi kabul eder ancak buna karşılık Allah'tan arz-ı mukaddeseye bir taş atımı من الأرض) ( uzaklıkta ölmeyi diler. ${ }^{55}$

Hz. Peygamber çoğunlukla sabah namazlarından sonra cemaate döner ve bir rüya gören varsa onu dinler yahut kendisi gördüğü rüyadan bahsederdi. İşte böyle bir zamanda Rasûlullah yine rüya gören olup olmadığını

51 Buhârî, el-Amel fi's-salât 9 (no: 1150).

52 Hz. Ömer rivâyeti için bkz. Buhârî, Teyemmüm 3 (no: 331). Aynı anlamda Ammâr rivâyeti: Teyemmüm 4 (no: 336), Teyemmüm 7 (no: 340).

53 Buhârî, Muzâraa 15 (no: 2219). Bir sonraki babda ise İbn Abbas ve Râfi' b. Hadîc'den naklen, arazinin altın, gümüş ve ürün karşılı̆̆ında kiraya verilebileceği hakkında görüşler verilmiştir. Bkz. Muzâraa 16 (no: 2220).

54 Enes rivâyeti için bkz. Buhârî, Menâkıb 22 (no: 3421).

55 Buhârî, Cenâiz 67 (no: 1274), Enbiyâ 32 (no: 3226). "Arz-1 mukaddese" tabiri Kur'ân'da da geçer. Burada yer alan bilgilere göre Hz. Musa kavmine şöyle seslenmiştir: "Ey kavmim! Allah-

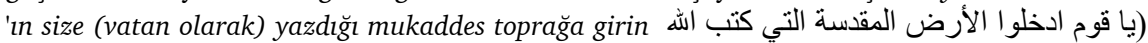
( ve arkaniza dönmeyin; yoksa kaybederek dönmüş olursunuz." Bkz. Mâide, 5/21. Bu âyetteki "el-arzu'l-mukaddese" tabirini er-Râğıb el-İsfehânî (ö. 425'ler), necasetten yani şirkten temizlenmiş yer olarak anlamışır. Bkz. Müfredâtu elfâzi'l-Kur'ân, s. 660, "k-d-s" md., thk. Safvân Adnân Dâvûdî, Beyrut 1412/1992. Kur'ân'da anlatılan bu yerin neresi olduğu açıça belirtilmese de, bazı âlimlerin bu yerin Şam ve Mısır veya Mescid-i Aksâ'nın bulunduğu Kudüs ve Lübnan dağı çevresi yahut Fırat ile Mısır arasında bir yer olması gerektiği yönünde beyanlarda bulunduğunu öğreniyoruz. Bkz. Küçük, Abdurrahman, DİA, III, 444, "Arz-1 Mev'ûd" md., İstanbul 1991. 
sormuş, gören çıkmayınca kendisi gördüğ̈̈ rüyayı onlara anlatmıştır. Buradaki anlatıma göre, onun yanına iki adam gelmiş, ellerinden tutup onu arz-ı mukaddeseye (الى الأرض المقدسة) çıkarmışlardır. ${ }^{56}$

Hz. Ömer'in, Yahudi ve Hiristiyanları Hicâz bölgesinden من أرضل ( uzaklaştırdığından bahseden rivâyet ise arz-ı Hicâz ile ilgili kullanıma bir örnektir. ${ }^{57}$

Hz. Ebû Bekir'in hicret etmek üzere Habeş bölgesine doğru yola çıtığına dair (خرج أبو بكر مهاجرا نحو أرض الحبشة) şeklindeki ifadeler konuyla ilgili diğer bir misaldir. ${ }^{58}$

2. Arzın yaşadığımız "yeryüzü" ve üzerindeki her şey anlamında kullanılması.

Bu durumda arz Türkçedeki yerküre/dünya kelimeleriyle eşanlamlı olup "sema" kelimesinin mukabilidir. Sözgelimi;

"Şu geceniz var ya... Şüphesiz bundan yüz sene sonra, şu anda yeryüzünde bulunan hiç kimse (من هو على ظهر الأرض أحد) hayatta olmayacakttr. ${ }^{.59}$

"Yeryüzü (الأرض) benim için bir mescit ve temizleyici kılındl."60

"Şüphesiz bana yeryüzü hazinelerinin anahtarlart (مفاتيح خزائن الأرض) verildi." ${ }^{11}$

"Zaman, Allah'ın gökleri ve yeri yarattığı günkü يوم خلق الله السموات) و şsekline dönmektedir. Yul, on iki aydır..." ${ }^{162} \mathrm{Bu}$ rivâyette de açıkça görüldügüü üzere, Kur'ân'ın kullanımında olduğu gibi sema ve arzın birbirlerinin mukabili olarak kullanıldığına rivâyetlerde sıkça rastlıyoruz. Yine mesela Rasûlullah'a Müddessir suresinin nâzil olma anının anlatıldığ

56 Semure b. Cündeb rivâyeti için bkz. Buhârî, Cenâiz 91 (no: 1320).

57 İbn Ömer rivâyeti için bkz. Buhârî, Muzâraa 14 (no: 2213), Humus 19 (no: 2983). Ebû Hureyre'den merfû olarak nakledilen bir rivâyette ise Hicâz kelimesi kullanılmadan "bu bölge" şeklinde bir anlatım vardır. Bu rivâyette arzın/yeryüzünün Allah'ın ve Rasûlü'nün olduğu vurgulanarak Yahudilerin Müslüman olmaları istenmekte, aksi takdirde bu bölgeden çıkarılacakları ifade edilmektedir. Bkz. Buhârî, Cizye 6 (no: 2996), İkrâh 2 (no: 6545), İ'tisâm 18 (no: 6916).

58 Âişe rivâyeti için bkz. Buhârî, Fezâilu's-sahâbe 74 (no: 3692).

59 İbn Ömer rivâyeti için bkz. Buhârî, İlim 41 (no: 116), Mevâkîtu's-salât 19 (no: 539), 39 (no: 576).

60 Câbir b. Abdillah rivâyeti için bkz. Buhârî, Teyemmüm 1 (no: 328), Mesâcid 23 (no: 427).

61 Ukbe b. Âmir rivâyeti için bkz. Buhârî, Cenâiz 71 (no: 1279), Menâkıb 22 (no: 3401), Meğâîn 25 (no: 3857), Rikâk 7 (no: 6062), 53 (no: 6218). Benzer ifadelerle: "Ben uyurken, yeryüzü hazinelerinin anahtarları bana getirildi ve elime konuldu." şeklinde nakledilen bir Ebû Hureyre rivâyeti için bkz. Buhârî, Cihâd 120 (no: 2815), Meğâzî 66 (no: 4116), Ta'bîr 11 (no: 6597), 22 (no: 6611), 40 (no: 6630), İ'tisâm 1 (no: 6845).

62 Ebû Bekre rivâyeti için bkz. Buhârî, Bed'ü'l-halk 2 (no: 3025). 
ne mesela Rasûlullah'a Müddessir suresinin nâzil olma anının anlatıldı̆̆g bir rivâyette de Hz. Peygamber'in kendisine Hirâ'da gelen meleği sema ile arz arasında bir kürsî üzerinde (على كرسي بين السماء والأرض) gördüğ̈ü anlatılarak bu iki kelime arasındaki mukabil anlama dikkat çekilmiştir. ${ }^{63}$ Aynı şekilde, Rasûlullah'ın sıkıntı anlarında sıkça yaptı̆̆ duaları arasında yer alan: "Göklerin ve yeryüzünün Rabbi!" (رب السموات و الأرض) şeklindeki tavsifi de bu iki kelimenin birlikte kullanımına güzel bir örnektir. ${ }^{64}$

"Allah bir kulu sevdiğinde Cibrîl'e şöyle nidâ eder: 'Şüphesiz ki Allah filanı seviyor, sen de onu sev!' Bunun üzerine Cibrîl de onu sever. Sonra Cibrîl semâ ehli içinde: 'Allah filanı seviyor, siz de onu sevin!' diye seslenir ve semâ ehli de onu sever. Sonra o kişi yeryüzünde kabul ile karşllanır."65 يوضع له الهض ( ) الأرض القبول ف

"Allah cehennem azabr en hafif olan kişiye şöyle sorar: 'Şayet yeryüzündeki her şey (ما في الأرض من شيئ) senin olsa, onu feda eder miydin?' O kişi evet diye cevap verir. Allah: 'Halbuki sen Âdem'in sulbündeyken senden bundan daha kolay bir şey istemiştim: Bana şirk koşmaman! Ama sen illa da şirk diye direttin!' buyurur."66

İslâm'ın ilk dönemlerinde Hz. Peygamber bir gün yatsı namazını kıldırmak üzere insanların yanına gecenin geç vaktine kadar çıkmamıştı. En nihayet Hz. Ömer'in kadın ve çocukların artık uyuklamaya başladıklarını hatırlatması üzerine Rasûlullah (s.a.), gecenin bu vaktine kadar bekleyen bu insanları şöyle diyerek müjdelemiştir: "Şu anda sizin dışınızda yeryüzünde yaşayanlardan hiç kimse (من أهل الأرض غيركم) namazı beklemekte değildir." ${ }^{167}$

"Benden sonra sizin hakkınızda korktuğum şey ancak, yeryüzünün bereketlerinin (بركات الأرض) size açılmasıdır."68 Burada geçen yeryüzü bereketlerinin rivâyetin hemen devamında "dünyanın süsü" (زلارة (لداني) olarak tefsir edilmesi, dünya ve arz kelimelerinin birbirlerinin yerine

63 Câbir b. Abdillah rivâyeti için bkz. Buhârî, Bed'ü'l-halk 7 (no: 3066), Tefsîr 405 (no: 4642). Aynı rivâyetin devamında arz kelimesinin bir de toprak/arazi/yer anlamında kullanıldığı görülmektedir.

64 İbn Abbas rivâyeti için bkz. Buhârî, Deavât 26 (no: 5985, 5986), Tevhîd 22 (no: 6990). Sema ve arz kelimelerinin mukabil olarak bir arada kullanıldı̆̆ı diğer örnekler için bkz. İbn Abbas rivâyeti: Buhârî, Ta'bîr 47 (no: 6639, iki ayrı yerde); Ebû Hureyre rivâyeti: Buhârî, Tefsîr 174 (no: 4407).

65 Ebû Hureyre rivâyeti için bkz. Buhârî, Bed'ü'l-halk 6 (no: 3037), Edeb 41 (no: 5693), Tevhîd 33 (no: 7047).

66 Enes'in merfû rivâyeti için bkz. Buhârî, Enbiyâ 2 (no: 3156). Krş. Buhârî, Rikâk 49 (no: 6173), 51 (no: 6189).

67 Hz. Âişe rivâyeti: Buhârî, Mevâkîtu's-salât 21 (no: 541), 23 (no: 544, 545), Sıfatu's-salât 77 (no: 824), 78 (no: 826); İbn Ömer rivâyeti: Mevâkîtu's-salât 23 (no: 545).

68 Ebû Saîd el-Hudrî rivâyeti için bkz. Buhârî, Cihâd 37 (no: 2687), Rikâk 7 (no: 6063). 
sir edilmesi, dünya ve arz kelimelerinin birbirlerinin yerine kullanımına dair ilginç bir örnektir.

Ebû Zerr, Rasûlullah'a yeryüzünde ilk inşa edilen (وضع في الأرض أول) mescidin hangisi olduğunu sorduğunda, onun Mescid-i Harâm olduğunu öğreniyor. ${ }^{69}$

Sa'd b. Ebî Vakkâs: "Peygamber'in (s.a.) Abdullah b. Selâm hariç yeryüzünde yürüyen/hayatta olan (يمشي على الأرض) hiç kimse hakkında cennetlik olduğunu söylediğini işitmedim." demektedir. ${ }^{70}$

Câbir b. Abdillah, Rasûlullah'ın kendileri hakkında Hudeybiye gününde, "Yeryüzünde yaşayanların en hayırlılart" (خير أهل الأرض) tabirini kullandığını belirtir. ${ }^{71}$

İbn Abbas'in haber verdiğine göre, bir gün Rasûlullah beraberinde bulunan bir grup ashâbıyla birlikte Ukâz çarşısına doğru yola çıkmış; bu sırada şeytanların semadan gizlice almaya çalıştıkları haberler kesintiye uğramıştı. Bu durumu aralarında tartışan şeytanlar, iletişimin kesilmesinin sebebini araştırmak üzere gönderdikleri yandaşlarına şu emirleri vermiştir: "Yeryüzünün doğu ve batı taraflarına (مشارق الأرض ومغاربها) dağılın ve semadan gelen haber ile aranıza giren bu şeyi araştırın..."72

Enes b. Mâlik'ten nakledilen bir rivâyete göre Rasûlullah ve beraberindekiler bir gün bir cenazeye rastlarlar. Oradakiler cenazeyle ilgili övgü dolu sözler söyleyince Hz. Peygamber "vacip oldu" der. Daha sonra başka bir cenazeyle daha karşılaştıklarında bu defa insanlar ölen kişinin aleyhine bir şeyler söyler, Hz. Peygamber yine "vacip oldu" der. Bunun sebebini öğrenmek isteyen Hz. Ömer'e Rasûlullah şu açıklamada bulunur: "Hayırla yad ettiğiniz kişiye cennet vacip oldu; şerli olarak andığınız kişiye de ateş

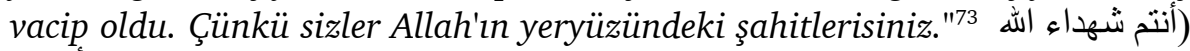

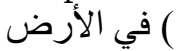

İbn Abbas'ın ifadesiyle insanlar, hac aylarında umre yapılmasını yeryüzündeki günâhların en büyüğ̈u (من أفجر الفجور في الأرض) olarak görürlerdi. $^{74}$

İbn Ömer'den nakledilen bir rivâyette, bir kediyi hapsedip onun dışarı çımmasına müsaade etmeyen ve aç bir şekilde ölmesine sebep olan bir kadının âhirette cehennem azabına duçar olmasının gerekçesi olarak, kadı-

69 Buhârî, Enbiyâ 12 (no: 3186).

70 Buhârî, Fezâilu's-sahâbe 49 (no: 3601), Edeb 55 (bab başlı̆̆ında).

71 Buhârî, Meğâzî 33 (3923).

72 Buhârî, Sifatu's-salât 23 (no: 739), Tefsîr 399 (4637).

73 Buhârî, Cenâiz 84 (no: 1301), Şehâdât 6 (no: 2499).

74 Buhârî, Hac 33 (no: 1489), Fezâilu's-sahâbe 56 (no: 3620). 
nın kediyi aç-susuz bırakmasının yanı sıra onun dışarı çıkıp hiç olmazsa yeryüzünün haşeratından (من خشاش الأرض) yemesine bile izin vermemesi gösterilir. ${ }^{75}$

Bazı rivâyetlerdeki anlatımlarda arz, Allah Teâlâ'nın kelâmına ve emirlerine muhatap olmaktadır. Mesela Ebû Hureyre'den gelen bir rivâyette Allah'ın arza, içinde bulunan şeyleri toplaması emrini verdiğini فأمر الله görüyoruz. ${ }^{76}$ Yine aynı sahâbîden nakledildiğine göre, âhiret gününde Allah Teâlâ'nın yeryüzünü sımsıkı kavrayıp gökleri düreceği (يقبض الهه الأرض ويطوي السموات) ve: "(Bugün) Melik benim! Yeryüzünün melikleri ya nerede?" (أين ملوك الأرض) diye buyuracağ1 Hz. Peygamber tarafindan haber verilmektedir. ${ }^{77}$

Arz kelimesi bir yerde ise yine ehlu'l-arz (أهل الأرض) şekliyle fakat bu defa ehlu'z-zimme (أهل الذمة) anlamında kullanılmıştır. Sehl b. Huneyf ve Kays b. Saîd'in birlikte bulundukları bir sırada yanlarından bir cenaze geçer ve onlar ayağa kalkarlar. Onlara cenazenin ehlu'l-arzdan yani ehlu'zzimmeden (انها من اهل الأرض أي من أهل الذمة) olduğu söylenince onlar Hz. Peygamber'in de aynı şekilde davrandığını söylerler. Rasûlullah da yanından bir cenaze geçince ayağa kalkmış, onun bir Yahudinin cenazesi olduğu söylenince de: "O da bir insan değil mi ki?" şeklinde karşllık vermiştir. ${ }^{78}$

\section{Sonuç}

Dünya ve arz kelimelerinin Sahîhu'l-Buhârî'deki kullanımlarını incelediğimiz bu çalışma sonucunda şu sonuçlara ulaştığımızı söyleyebiliriz:

"Dünya" kelimesi tespit edebildiğimiz kadarıyla başlıca dört değişik şekilde kullanılmıştır: Bunlardan birincisine göre dünya, sözlük anlamı göz önünde bulundurularak "yakınlık" manasında kullanılmıştır. İkinci olarak, âhiretin mukabili olmak üzere ölümden önceki hayatı anlatmak için bu kelimenin kullanıldığını görüyoruz. Üçüncü kullanımda dünya, üzerinde yaşadığımız yeryüzü anlamına gelir. Ancak dünya kelimesinin bu şekilde doğrudan Türkçedeki yeryüzü anlamında ve arz kelimesiyle müteradif olarak kullanımının yaygın olduğunu söylememiz zordur. Son olarak dünya kelimesi, dünyalık menfaatleri veya yeryüzünde yer alan sayısız nimetleri anlatmak için kullanılmışır. "Dünyadan ve onun içindekilerden daha

75 Buhârî, Müsâkât 10 (no: 2236), Bed'ü'l-halk 16 (no: 3140), Enbiyâ 52 (no: 3295). Bu rivâyetteki arzın yeryüzü anlamının yanı sıra toprak/yer manasında olması da makul görünmektedir.

76 Buhârî, Enbiyâ 52 (no: 3294).

77 Buhârî, Tefsîr 298 (no: 4534), Rikâk 44 (no: 6154), Tevhîd 6 (no: 6947), 19 (no: 6977). Krş. Ebû Saîd rivâyeti: Buhârî, Rikâk 44 (no: 6155).

78 Buhârî, Cenâiz 48 (no: 1250). 
hayırlıdır" üslubuyla dile getirilen bu kullanımda dünya kelimesinin Türkçedeki yeryüzü anlamında olabileceği düşünülebilirse de, kanaatimizce onunla daha çok, yeryüzü üzerinde bulunan şeylerin çokluğu vurgulanmış olmaktadır. İbn Dakîykı'l-Iyd'in, İbn Hacer'den naklen kaydettiğimiz yorumu dikkate alındığında bu kanaatimizin doğru olduğu ortaya çıkmaktadır.

"Arz" kelimesine gelince; birinci olarak arz, toprak, arazi, arsa ve yer gibi anlamlarda kullanılmıştır. İkinci olarak bu kelime, arz-ı Mukaddese, arz-ı Hicaz ve arz-ı Habeş gibi kullanımlarla belli bir bölgeyi anlatır. Arzın üçüncü anlamı, Türkçedeki dünya yani üzerinde yaşamakta olduğumuz yeryüzü ve yerküredir. Dördüncü olarak ise ehlü'l-arz şeklindeki kullanımı ile ehlü'z-zimme anlamında kullanılmıştır.

Sonuç olarak, Buhârî'nin kitabındaki rivâyetlerin büyük bir çoğunluğunun dünya ve arz kelimelerinin kullanımı konusunda Kur'ân-1 Kerim ile örtüştüğünü söylememiz mümkün gözükmektedir. 